\title{
PROTECTION EFFECT OF VAXXITEK HVT + IBD VACCINE AGAINST INFECTIOUS BURSAL DISEASE IN BROILER CHICKENS
}

\author{
M. H. Rashid, H. Luo', J. Akhter', M. T. Islam³, M. R. Islam4, M. M. Rahman", \\ Y. Cao' ${ }^{1}$ and C. Xue ${ }^{1 *}$ \\ Department of Microbiology, Jhenaidha Government Veterinary College, Jhenaidha
}

\begin{abstract}
The very virulent infectious bursal disease virus (vvIBDV) infection cause constant and frequent outbreaks of IBD. In order to prevent the disease caused by vvIBDV, moderate-virulent live vaccines are usually used in broilers, but these vaccine influence the immune system of chickens and cause the immunosuppression. VAXXITEK $^{\circledR}$ HVT+IBD bivalent vaccine, a novel vaccine produced by Merial Company, is the recombinant vaccine generated by inserting IBDV VP2 gene into the HVT genome. The recombinant vaccine could prevent Marek's disease and IBD of chickens at the same time after vaccinated by the subcutaneous route at 1-dayold. The objective of this study was to evaluate protection effect of this new vaccine against IBD in broilers. The results of the lab and field immunization trial showed that the vaccination of VAXXITEK ${ }^{\circledR}$ HVT+IBD vaccine did not damage the bursa of broilers; the level of IBD antibody of the VAXXITEK ${ }^{\circledR}$ HVT+IBD vaccination groups was higher than IBD-BLEN ${ }^{\circledR}$ vaccination groups at 21-day-old; the protection effect of the VAXXITEK ${ }^{\circledR}$ HVT + IBD vaccination groups was better than IBD-BLEN $^{\circledR}$ vaccination groups, especially at 21-28 day. The results indicated that VAXXITEK ${ }^{\circledR}$ HVT + IBD vaccine could provide better protection to broiler chickens against IBD.
\end{abstract}

Key Words: Infectious bursal disease virus, VAXXITEK ${ }^{\circledR}$ HVT + IBD bivalent vaccine, IBD-BLEN ${ }^{\circledR}$ vaccine, Protection effect

\section{INTRODUCTION}

Infectious bursal disease (IBD) caused by infectious bursal disease virus (IBDV) has been of great concern to the poultry industry for a long time around the world. IBDV is a member of the genus Avibirnavirus of the family Birnaviridae. The IBDV genome consists of 2 segments of double-stranded RNA (dsRNA) and a nonenveloped icosahedral capsid (Muller et al., 1979). The disease is highly contagious in young chickens. The economic impact of the disease depends upon the IBDV strain, the chicken breed (White Leghorns are more susceptible than yellow-feather broilers and brown-egg layers), concurrent primary or

\footnotetext{
1State Key Laboratory of Biocontrol, Department of animal molecular virology and animal viral immunology, School of Life Sciences, Sun Yat-Sen University, Guangzhou, 510006, P R China 2Upazila Livestock Office, Islampur, Jamalpur, Bangladesh

3Department of Medicine, Bangladesh Agricultural University, Mymensingh-2202, Bangladesh 4Department of Medicine and Surgery, Sylhet Agricultural University, Sylhet-3100, Bangladesh *Corresponding author (Email: xuechy@mail.sysu.edu.cn)
} 
secondary pathogens, as well as environmental and management factors (Müller et al., 2003). At the end of the 1980s, antigenic variants in the United States of America and very virulent (vv) IBDV strains in Europe (antigenically similar to the "classical strains") emerged in vaccinated flocks and rapidly spread all over the world. The vvIBDV can cause $100 \%$ mortality in experimentally infected specific pathogen free (SPF) chickens, and mortality rates of $60 \%$ and $30 \%$ have been reported in layers and broilers respectively in field conditions (Van den Berg et al., 2004 and Van den Berg et al., 1991).

The IBDV destroys the precursors of antibody producing cells in the bursa of Fabricius, particularly immunoglobulin B-bearing B lymphocytes inducing bursal atrophy, mortality, and/or immunosuppression in unprotected flocks (Becht et al., 1988; Sharma et al 2000). Immunosuppression increases the susceptibility of chicks to opportunistic microorganisms in the environment (Homer et al., 1992) and lowers responsiveness to vaccination (Faragher et al., 1974). Prevention of avian diseases can be achieved by biosecurity; however, Infectious bursal disease virus (IBDV) is highly resistant to adverse environmental conditions, as a result the pathogens persist in chicken houses; therefore, the control of this disease depends mainly on vaccination (Al-Natour et al., 2004). Despite active role of cellular immunity, neutralizing antibodies are essential for the protection against IBDV. Inactivated oil-adjuvant vaccines are commonly used to induce high antibody titers in breeders prior to the onset of lay, which will then be passively transmitted to the offspring. In the early life, maternal derived antibody (MDA) provides passive protection against infection. An attenuated virus vaccine is widely practiced to control IBD, but their major constrain is the sensitivity to maternally derived antibodies (MDA) which are found at the time of vaccination. To overcome this problem less attenuated vaccines "intermediate" or "hot" vaccines can be used (Prandini et al., 2008). The major problem with less attenuated vaccines is induction of lesions in the bursa of Fabricius as found in specific pathogen free (SPF) birds (Rautenschlein et al., 2005). An immune complex (IC) vaccine is used for in ovo or for s.c. day old vaccination, in which the "intermediate plus" vaccine virus is complexes with antibodies. It has been suggested that the IC is taken up by follicular dendritic cells (macrophages) where the virus resides until the drop of MDA (Prandini et al., 2008).

Vectored viral vaccines expressing proteins of IBDV have also been described as potential IBD vaccines, using vectors such as fowl pox virus, turkey herpes virus (HVT) (Darteil et al., 1995), fowl adenovirus, Marek's disease virus and Semliki Forest virus (Müller et al, 2003; Saif 1998 and Van den Berg et al., 2004). The parental strain of HVT has been widely used in vaccination against Marek's disease, and is well known for safety, efficacy and less sensitive to MDA interference, this is why it was developed as a vector for IBD (Darteil et al., 1995; Goutebroze et al., 2003). The HVT recombinant virus vHVT013-69 (vHVT13) was produced by insertion of an IBDV VP2 gene into the HVT genome. VAXXITEK ${ }^{\circledR}$ HVT + IBD can be administered either in ovo ( 3 days before hatching) or by the subcutaneous route in 1-day old chickens, in the presence of high titers of MDA (Bublot et al., 2007). However, there are few reports of VAXXITEK ${ }^{\circledR}$ HVT+IBD vaccine efficacy to control IBD in yellow-feather broilers in China. The aim of this study was to ascertain the efficacy of this novel vaccine in both laboratory and field conditions to control IBDV in broilers. 


\section{MATERIALS AND METHODS}

\section{Experimental design and virus challenge}

Experiment No. 1: A total of 270 broilers were divided into 12 groups, groups 1-3 contained 30 birds each and groups 4-12 contained 20 birds each. Groups 1, 5, and 9 were administered with VAXXITEK ${ }^{\circledR}$ HVT + IBD (a registered trademark of Merial in the United States of America and elsewhere) vaccine at 1 day of age according to the manufacturer's recommendation; groups 2,6 , and 10 were immunized orally with the IBD-BLEN ${ }^{\circledR}$ (a registered trademark of Merial in the United States of America and elsewhere) vaccine at 10 days old according to the manufacturer's recommendation. Groups 3, 4, 7, 8, 11, and 12 remained unvaccinated as control. Blood samples were randomly taken from 10 birds of each group at the ages of $1,7,14,21,28,35,42$, and 56 days. The antibody titers of the birds were tested for each blood sample by the PROFLOK ${ }^{\circledR}$ plus IBD Ab (a registered trademark of Synbiotics in the United States of America and elsewhere) antibody test kit. At 14 days (i.e. 96 hours after vaccination with IBD-BLEN ${ }^{\circledR}$ vaccine) and 21 days of age, 5 birds from each group of 2,6, and 10 were examined, weighed and sacrificed. The bursas and spleens were collected and weighed. Relative bursa and spleen body weights were obtained using the formula [relative bursa weight $=($ bursa weight $/$ body weight $) \times 1000$ ] or [relative spleen weight $=($ spleen weight/body weight $) \times 1000]$. All the birds were challenged with a vvIBDV strain HK46 (Cao et al., 1998) at 21 days in groups 1-4, at 28 days in groups 5-8 and 35 days in groups 9-12. The challenge dose was $100 \mathrm{LD}_{50}$ per bird administered via the ocular route of the chicken. All the birds were observed for 5 days for clinical signs of IBD. Morbidity, mortality, and bursa/spleen body weight ratios were recorded. At 120h post challenge, all the survived birds were sacrificed, and bursa and spleen body weight ratios were calculated. The IBDV infection was identified by swollen or atrophy of the bursa, hemorrhage in the bursa and breast muscles, and death of the birds after challenge.

Experiment No. 2: A total of 180 broilers were divided into 9 groups with 20 birds each. Immunization program and virus challenge tests were also performed. Groups 1, 4, and 7 were administered with VAXXITEK ${ }^{\circledR}$ HVT+IBD vaccine at 1 day of age, groups 2,5 , and 8 were immunized orally with IBD-BLEN ${ }^{\circledR}$ vaccine at 10 days of age, and groups 3,6 , and 9 remained unvaccinated as control. All the birds were challenged with a vvIBDV strain HK46 (Cao et al., 1998) at 21 days in groups 1-3, at 28 days in groups 4-6, and at 35 days in groups 7-9. The challenge dose was $1000 \mathrm{LD}_{50}$ per bird administered via the ocular route of the chicken; it was done by Experiment no.1's procedure to determine whether the chickens were infected with IBDV.

Experiment No. 3: In field test, 14 commercial farms in different regions of Guangdong province, China were selected randomly and divided into two groups: VAXXITEK ${ }^{\circledR}$ HVT+IBD (7 farms) and IBD-BLEN ${ }^{\circledR}$ vaccine (7 farms). All the birds were challenged with a vvIBDV strain HK46 (Cao et al., 1998) at 21 days in groups 1-3, at 28 days in groups 4 and 5, and at 35 days in groups 6 and 7. The challenge dose was 1000LD 50 per bird administered via the ocular route of the chicken; it was done by Experiment no.1's procedure. The broilers of the same age were selected. The feed formulations of the farms were the same and the chickens had free access to water and feed. The management systems were monitored 
critically. The 1-day-old chickens of the first trial group (7 farms) were vaccinated by the subcutaneous route with VAXXITEK ${ }^{\circledR}$ HVT+IBD vaccine. The 10-day-old chickens of the other group (7 farms) were vaccinated with drinking water with the IBD-BLEN ${ }^{\circledR}$ vaccine. Blood samples were taken from 15 birds of each group at 1, 14, 21, 28, 35, 42, and 56 days. The antibody titers of the birds were tested using the PROFLOK ${ }^{\circledR}$ plus IBD Ab antibody test kit for each blood sample. The bursal histopathological lesion scores were monitored from 5 birds of each group at 7, 14, 21 and 35 days of age. At the end of the experiment, feedconversion ratios (FCR) were calculated. FCR were calculated as the total weight of food consumed by the chickens divided by the total live weight gain of the chickens.

\section{Serology}

The sera obtained from the field and laboratory birds at various time points were tested for IBD antibodies using the PROFLOK ${ }^{\circledR}$ plus IBD Ab test kit (Symbiotics, San Diego, CA). The antigen used by this kit is a purified extract from IBDV infected bursa (Le Gros et al., 2009). Antibody titers were measured before and after viral challenge. The results were expressed in titer $\left(\log _{10}\right)$, as recommended by the diagnostic kit producer.

\section{Bursal histopathology}

The severity of the bursal histological change was scored on a scale from 1 to 4 as described before (Rosales et al., 1989). In brief, $1=$ normal, or up to $10 \%$ follicular atrophy; $2=$ focal, mild scattered cell depletion, or 10\%-30\% follicular atrophy; $3=$ multifocal follicular atrophy of $30 \%-70 \% ; 4=$ diffuse atrophy of $>70 \%$ of the follicles or any evidence of acute necrosis (Rosales et al., 1989).

\section{Statistical analysis}

All data were entered into a spreadsheet programmes (Excel 2000; Microsoft Corporation) and transferred to SPSS 16.0 software. Data of different parameters were analyzed using Student $t$ test and analysis of variance (ANOVA) where applicable. The difference between parameters was regarded as significant when the $p$ value was less than 0.05 .

\section{RESULTS}

\section{The effect of vaccination on the immune organ of broiler}

Four days after vaccination with IBD-BLEN ${ }^{\circledR}$ (at 14 days of age), 5 chickens from each group (VAXXITEK ${ }^{\circledR}$ HVT + IBD vaccine groups, IBD-BLEN ${ }^{\circledR}$ vaccine groups and control groups) were sacrificed for measuring bursa and spleen body weight ratios. The IBD-BLEN ${ }^{\circledR}$ vaccine groups showed significantly $(\mathrm{P}<0.05)$ higher swollen of bursa than VAXXITEK ${ }^{\circledR} \mathrm{HVT}+$ IBD vaccine groups and control groups (Fig. 1). There were no significant differences in spleen/body weight ratios (data not shown).

\section{Virus challenge}

At 21 days after challenge with $100 \mathrm{LD}_{50}$, groups 1, 2, and 3 showed no significant morbidity and mortality. After dissection in groups 1, 2, and 3, bursal lesions were found in 2, 5, and 20 birds respectively; the protection level was $90 \%, 75 \%$ and 0 respectively. The Spleen/body weight ratios of groups 1, 2, 3, and 4 were $1.95 \pm 0.185,2.19 \pm 0.151,2.27 \pm$ 
$0.158,1.76 \pm 0.251$, respectively. At $120 \mathrm{~h}$ after virus challenge, all the groups showed some degree of bursal atrophy and spleen enlargement; the VAXXITEK ${ }^{\circledR}$ HVT + IBD vaccine groups showed significantly $(\mathrm{P}<0.05)$ smallest degree of bursal atrophy (Table 1$)$ and spleen enlargement (data not shown).

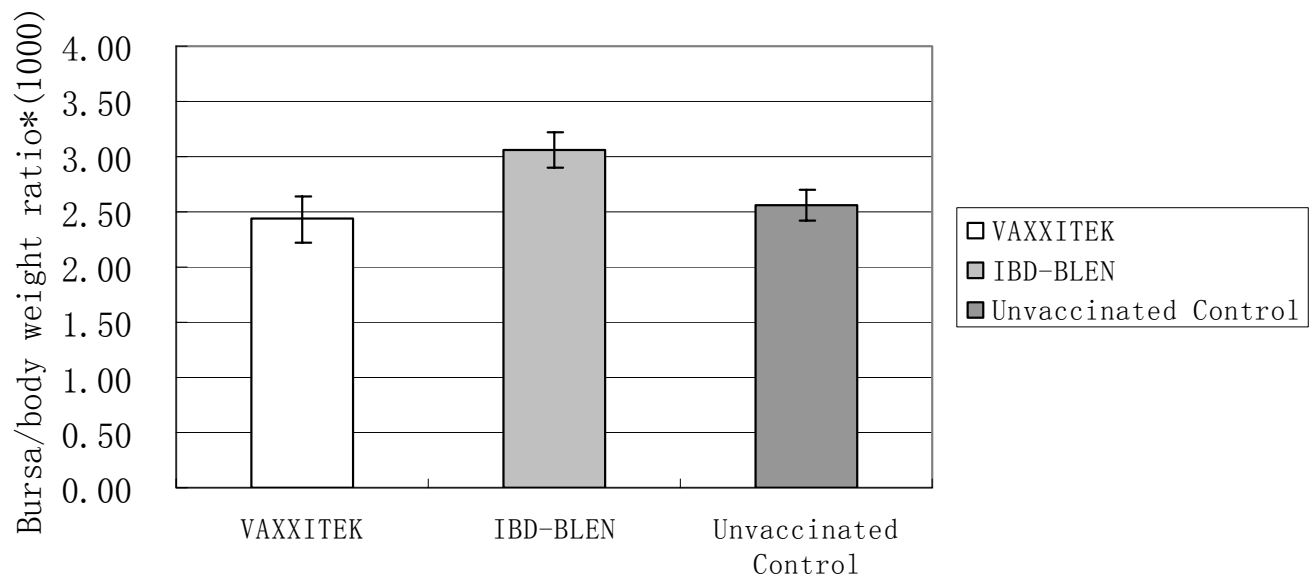

Fig. 1. Average bursa/body weight ratio at 14 days of age. The IBD-BLEN ${ }^{\circledR}$ vaccine groups showed significantly $(\mathrm{P}<0.05)$ higher swollen of bursa than VAXXITEK ${ }^{\circledR}$ HVT + IBD vaccine groups and control groups

Table 1. Average bursa/ body weight ratio analysis of the three groups at 26 days, 33 days, and 40 days

\begin{tabular}{l|c|c|c}
\hline \multicolumn{1}{c|}{ Groups } & Day 26 & Day 33 & Day 40 \\
\hline VAXXITEK & $2.28 \pm 0.24^{\mathrm{a}}$ & $2.55 \pm 0.19 \mathrm{a}$ & $2.29 \pm 0.21^{\mathrm{a}}$ \\
IBD-BLEN & $1.55 \pm 0.21^{\mathrm{b}}$ & $1.33 \pm 0.08^{\mathrm{b}}$ & $0.84 \pm 0.10^{\mathrm{b}}$ \\
Unvaccinated control & $1.38 \pm 0.12^{\mathrm{b}}$ & $1.11 \pm 0.05^{\mathrm{b}}$ & $0.89 \pm 0.19 \mathrm{~b}$ \\
\hline
\end{tabular}

$a, b$ Values within the same column differed significantly $(\mathrm{P}<0.05)$, Data represent mean $\pm \mathrm{SE}$, The bursa/body weight ratio was significantly $(\mathrm{P}<0.05)$ higher in VAXXITEK ${ }^{\circledR} \mathrm{HVT}+\mathrm{IBD}$ vaccine group at different days of post vaccination than the IBD-BLEN ${ }^{\circledR}$ and unvaccinated control group. No significant difference in bursa/body weight ratio was found between the IBD-BLEN ${ }^{\circledR}$ and unvaccinated control groups, which indicates that IBD-BLEN ${ }^{\circledR}$ did not affect the bursa of Fabricius

At 28 days after challenge with $100 \mathrm{LD}_{50}$, groups 5, 6, and 7 showed no significant morbidity and mortality. After dissection in groups 5, 6, and 7, bursal lesions were found in 2, 4, and 20 birds respectively; the protection level was $90 \%, 80 \%$ and 0 respectively. The Spleen/body weight ratios of groups 5,6,7,8 were $1.83 \pm 0.135,1.83 \pm 0.142,2.24 \pm 0.217$, respectively. At $120 \mathrm{~h}$ after virus challenge, the VAXXITEK ${ }^{\circledR}$ HVT + IBD groups showed normal bursa but the IBD-BLEN ${ }^{\circledR}$ and unvaccinated control groups showed moderate $(\mathrm{P}<0.05)$ degree of bursal atrophy (Table 1$)$ and spleen enlargement (data not shown). 
At 35 days after challenge with $100 \mathrm{LD}_{50}$, in groups 9, 10, and 11 had no occurrence of morbidity and mortality. After dissection, bursal lesions were found in 1 bird and protection levels were $95 \%$ in both groups 9 and 10 . The spleen/body weight ratios of groups 9, 10, 11, and 12 were $1.48 \pm 0.126,1.37 \pm 0.144,1.63 \pm 0.154,1.74 \pm 0.137$, respectively. At $120 \mathrm{~h}$ after virus challenge, the VAXXITEK ${ }^{\circledR} \mathrm{HVT}+\mathrm{IBD}$ groups showed normal bursa but the IBD-BLEN ${ }^{\circledR}$ and unvaccinated control groups showed significantly $(\mathrm{P}<0.05)$ higher bursal (Table 1) and spleen atrophy (data not shown).

Similar results were found after challenge with vvIBDV strain HK46 (Cao et al., 1998) at a dose of $1000 \mathrm{LD}_{50}$ per bird. At 21 days of age, the VAXXITEK ${ }^{\circledR} \mathrm{HVT}+\mathrm{IBD}$ groups and the IBD-2512 groups showed $60 \%$ and $20 \%$ protection respectively; at 28 days the protection levels were $65 \%$ and $55 \%$ respectively; at 35 days the protection levels of the both groups were $85 \%$.

\section{Antibody titers in the laboratory experimental groups}

Antibody titers of the laboratory experimental chickens are shown in Fig. 2. The result showed that at 21 days the antibody titers of VAXXITEK ${ }^{\circledR}$ HVT + IBD vaccine groups were significantly $(\mathrm{P}<0.05)$ higher than IBD-BLEN ${ }^{\circledR}$ vaccine groups. From $28-35$ days of age this group showed a high and steadily increasing level of antibody titers. The IBD-BLEN ${ }^{\circledR}$ vaccine groups at 21 days showed significantly $(\mathrm{P}<0.05)$ low level of antibody titers.

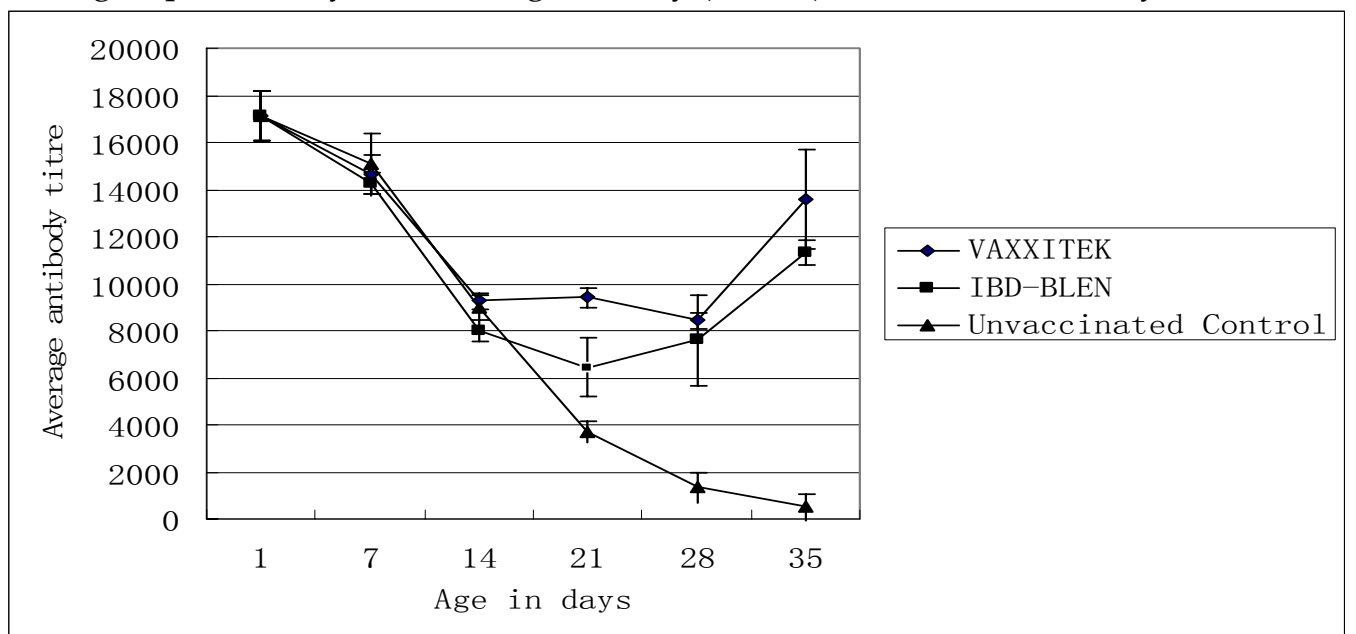

Fig. 2. The average antibody titers of the laboratory experimental chicken groups. Significant $(\mathrm{P}<0.05)$ difference was found at the age of 21 days in between the VAXXITEK ${ }^{\circledR}$ HVT + IBD vaccine groups and the IBD-BLEN ${ }^{\circledR}$ vaccine groups

\section{Antibody titers in the field experimental groups}

Antibody titers of the filed experimental chickens are shown in Fig. 3. The antibody titers decreased slowly during 1-21 days both in the VAXXITEK ${ }^{\circledR}$ HVT+IBD groups and the IBD$\mathrm{BLEN}^{\circledR}$ groups then rose during 21-56 days. The antibody titers of the VAXXITEK ${ }^{\circledR}$ HVT + IBD groups were significantly $(\mathrm{P}<0.05)$ higher than the IBD-BLEN ${ }^{\circledR}$ groups at 21 days and the titers of both groups were almost similar at 35 days and 56 days. 
PROFLOK plus IBD Ab test kit

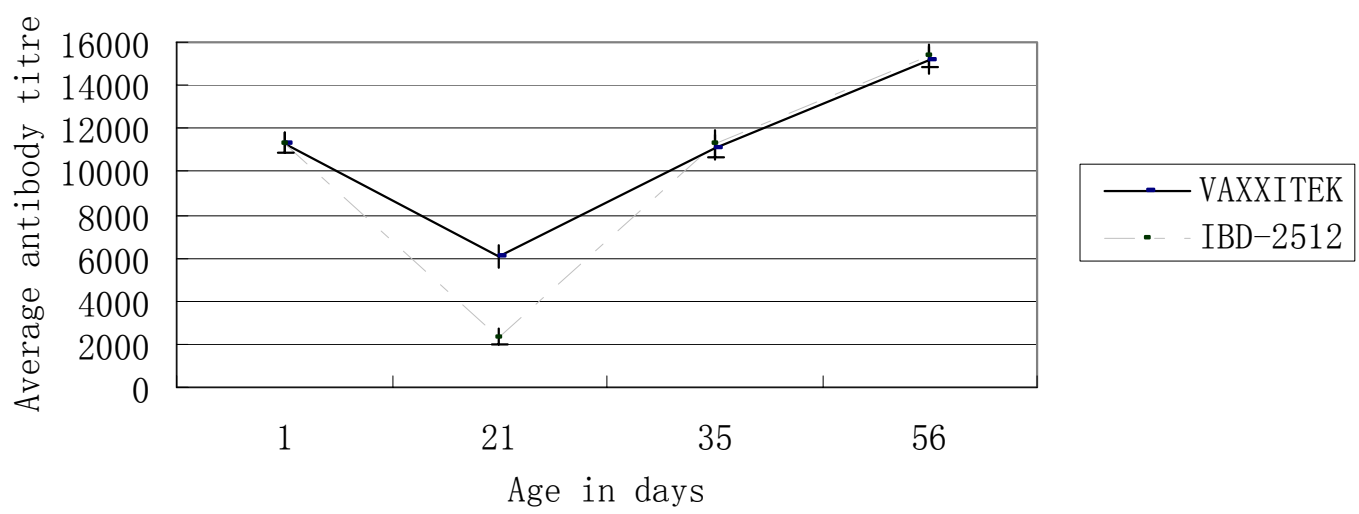

Fig. 3. The average antibody titers of the field experimental chicken groups, significant $(P<0.05)$ difference were detected at the age of 21 days in between VAXXITEK ${ }^{\circledR}$ HVT + IBD vaccine groups and the IBD-BLEN ${ }^{\circledR}$ vaccine groups

\section{Bursal histopathology}

There was no bursal lesion at 35 days in the VAXXITEK ${ }^{\circledR}$ HVT + IBD vaccine groups. There were bursal lesions from 21 days in the IBD-BLEN ${ }^{\circledR}$ groups, significantly $(\mathrm{P}<0.05)$ severe lesions were found at 28 days Fig. 4.

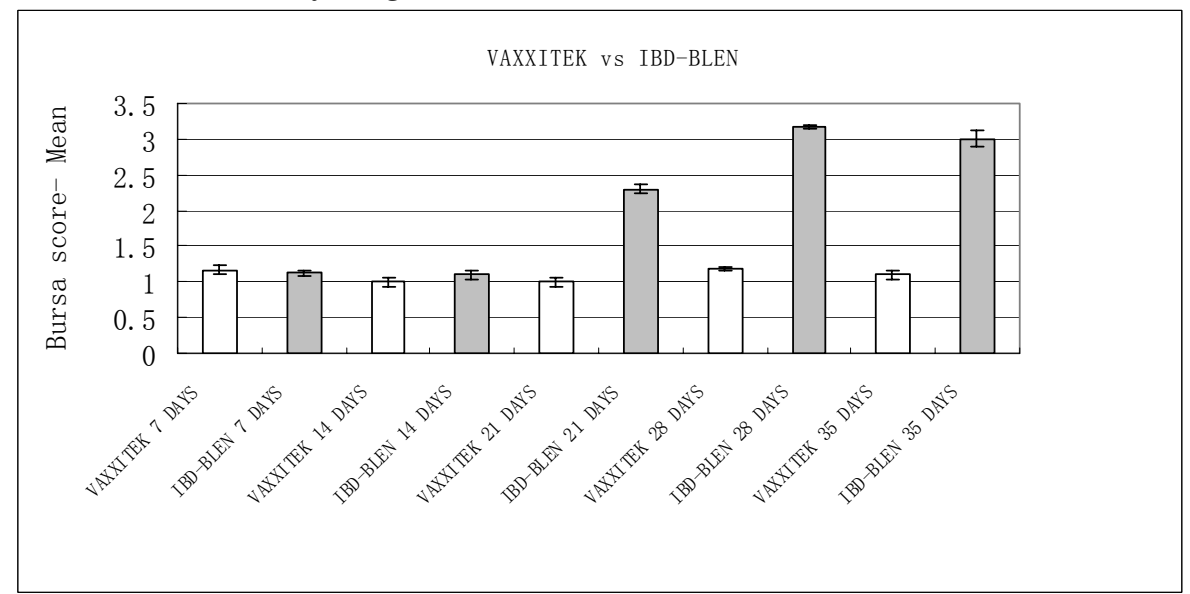

Fig. 4. The mean bursal histopathological lesion score of VAXXITEK ${ }^{\circledR}$ HVT + IBD and IBD-BLEN ${ }^{\circledR}$ vaccine groups. There was no bursal lesion at 35 days in the VAXXITEK ${ }^{\circledR}$ HVT + IBD vaccine groups. There were bursal lesions from 21 days in the IBD-BLEN ${ }^{\circledR}$ groups, significantly $(\mathrm{P}<0.05)$ severe lesions were found at 28 days

\section{Feed-conversion ratio (FCR)}

The FCR rate in field trial was $2.44 \pm 0.18$ in VAXXITEK ${ }^{\circledR}$ HVT + IBD groups while $2.46 \pm$ 0.21 in the control groups. There was no significant $(\mathrm{P}>0.05)$ difference of FCR in VAXXITEK ${ }^{\circledR} \mathrm{HVT}+\mathrm{IBD}$ and control groups. 


\section{DISCUSSION}

The object of this study was to find out a competent method to control IBDV in broiler chickens comparing the immunogenicity and efficacy of VAXXITEK ${ }^{\circledR}$ HVT + IBD and IBD$\mathrm{BLEN}^{\circledR}$ vaccine in presence of MDA. MDA provides passive protection against IBDV during the first few weeks of life, but continued protection must be maintained by administrating a vaccine before MDA decreases to a sub-protective level. However, MDA can create a major problem by interfering with IBD modified live vaccines (MLVs,) and thus can reduce the antigenic load needed for immunization. After the decline of MDA, birds which do not respond to vaccination are susceptible to IBDV infection.

The bursa/body weight ratios after $96 \mathrm{~h}$ of vaccination suggest immunosuppression in the IBD-BLEN ${ }^{\circledR}$ groups of chickens in the early stage of life (Darteil et al., 1995). After completing the virus challenges in different doses, it appears that the VAXXITEK ${ }^{\circledR}$ HVT+IBD vaccine groups have the capacity to protect chickens from IBDV infection; on the other hand, the IBD-BLEN ${ }^{\circledR}$ vaccine groups can not protect chickens in the early life. It was also observed that earlier challenges were difficult to interpret due to the hindrance of the passive immunity (Le Gros et al., 2009). The bursal lesion score results indicate that VAXXITEK ${ }^{\circledR}$ HVT+IBD vaccine groups are protected from the vvIBDV challenge, similar results were previously reported (Perozo et al., 2009). The efficiency of the vaccine could be justified by analyzing the challenge effect on bursa/body weight ratios of different groups. These results demonstrate that the VAXXITEK ${ }^{\circledR}$ HVT+IBD vaccine groups were clearly protected from challenge, whereas, the IBD-BLEN ${ }^{\circledR}$ groups were not protected. The bursal lesion score and the bursa/body weight ratios results indicate no interference of MDA with the protection provided by the VAXXITEK ${ }^{\circledR}$ HVT + IBD vaccine which has been previously described (Darteil et al., 1995); on contrary, the IBD-BLEN ${ }^{\circledR}$ groups are not sufficiently immunized to protect from IBVD challenge.

In this study, ELISA results explicate the immunity gap in groups vaccinated with IBDBLEN $^{\circledR}$ between 14 days and 28 days of age. At the age of 21 days, the date of the first challenge, these birds still depended on passive immunity to face the experimental challenge; this is why some birds showed clinical signs therefore exhibited a lower protection level. This condition also prevailed up to 28 days; this is clear evidence of an immunity gap. The induced active immunity was found in this group at the age of 30 days. This immunity gap is a classic representative of MLVs; in the field, this gap is overcome by multiple administrations of MLVs. The IBD-BLEN ${ }^{\circledR}$ vaccine schedule of this study was not successful in conquering this immunity gap as justified by serological tests. In contrast, the antibody titers of the VAXXITEK ${ }^{\circledR}$ HVT + IBD vaccination groups were consistently higher than IBD-BLEN ${ }^{\circledR}$ vaccine groups from 21 days to 56 days (using the PROFLOK ${ }^{\circledR}$ plus IBD test kit). As a result, no immunity gap was found in this period, which was the most vulnerable time in the face of the IBDV field challenge, indicating the vaccine efficacy was not affected by the presence of high levels of MDA. Hence, it can be administered either in ovo or at 1 day of age. The VAXXITEK ${ }^{\circledR}$ HVT + IBD vaccine has a cell-associated nature (consisting of vHVT13 infected chicken embryo fibroblasts). The lack of expression of VP2 on the surface of infected cells or of vHVT13 vectors, and the mode of replication of HVT 
vectors, probably all contribute to the ability of this vaccine to overcome MDA (Bublot et al., 2007). The VAXXITEK ${ }^{\circledR}$ HVT+IBD vaccine-induced, anti-VP2 antibodies can protect from a field challenge as already described (Bublot et al., 2007; Goutebroze et al., 2003) and as justified by this study. A previous report also confirmed similar immunogenicity induced by another field trial of an HVT-vectored IBD vaccine (Tsukamoto et al., 2002). The FCR rate in the VAXXITEK ${ }^{\circledR}$ HVT + IBD group indicates that the performance of this group is better than the control group; similar results were previously reported (Laszlo et al., 2008). The findings of this study are consistent with early reported observations (Bublot et al., 2007; Le Gros et al., 2005), exhibiting competent vaccination in the presence of MDA, without bursal lesions.

\section{CONCLUSION}

The laboratory test results and the field immunoassay results demonstrate that the IBDBLEN $^{\circledR}$ vaccine causes a certain degree of bursal damage in broiler chickens but the VAXXITEK ${ }^{\circledast}$ HVT+IBD vaccine causes no damage in the immune organ. Under the field conditions where antigenic variation and viral evolution poses a continuous threat in chickens, the VAXXITEK ${ }^{\circledR}$ HVT + IBD vaccine can demonstrates higher performance without immunity gap after in ovo or day-old vaccination, even in the presence of high MDA, compared with the IBD-BLEN ${ }^{\circledR}$ vaccine in the control of IBD in broiler chickens.

\section{ACKNOWLEDGEMENT}

The authors express their gratitude to Mr. Nicholas Fishbane, Department of Statistics, University of British Columbia, Canada, for proofreading the manuscript.

\section{REFERENCES}

Al-Natour, M. Q., Ward, L. A., Saif, Y. M., Stewart-Brown, B. and Keck, L. D. 2004. Effect of Different Levels of Maternally Derived Antibodies on Protection Against Infectious Bursal Disease Virus. Avian dis., 48: 177-182.

Becht, H., Müller, H. and Müller, H. K. 1988. Comparative studies on structural and antigenic properties of two serotypes of infectious bursal disease virus. J. Gen. Virol., 69: 631-640.

Bublot, M., Pritchard, N., Le Gros, F. X. and Goutebroze, S., 2007. Use of a vectored vaccine against infectious bursal disease of chickens in the face of high-titrated maternal derived antibody. J. Comp. Path., 137: 81-84.

Cao, Y. C., Yeung, W. S., Law, M., Bi, Y. Z., Leung, F. C. and Lim, B. L. 1998.Molecular characterization of seven Chinese isolates of infectious bursal disease virus: classical, very virulent and variant strains. Avian Dis., 42: 340-351.

Darteil, R., Bublot, M., Laplace, E., Bouquet, J. F., Audonnet, J. C. and Riviere, M. 1995. Herpesvirus of turkey recombinant viruses expressing infectious bursal disease virus (IBDV) VP2 immunogen induce protection against an IBDV virulent challenge in chickens. Virology., 211: 481-490.

Faragher, J. T., Allan, W. H. and Wyeth, P. J. 1974. Immunosuppressive effect of infectious bursal agent on vaccination against Newcastle disease. Vet. Rec., 95: 385-388. 
Goutebroze, S., Curet, M., Jay, M. L., Roux, C. and Le Gros, F. X. 2003.Efficacy of a recombinant HVTVP2 against Gumboro disease in the presence of maternal antibodies. Br. Poultr. Sci., 44: 824-825.

Homer, B. L., Butcher, G. D., Miles, R. D. and Rossi, A. F. 1992. Subclinical infectious bursal disease in an integrated broiler production operation. J.Vet. Diagn. Invest., 4: 406-411.

Laszlo, K., Janos, P., Laszlo, P. and Imre, S. 2008. Results of field experiments with Vaxxitek HVT plus IBD vaccine in Hungary.Magyar Allatorvosok Lapja., 130: 718-726.

Le Gros, F. X., Dancer, A., Giacomini, C., Pizzoni, L., Bublot, M., Grazini, M. and Prandini, F. 2009. Field efficacy trial of a novel HVT-IBD vector vaccine for 1-day-old broilers. Vaccine, 27: 592-596.

Le Gros, F. X., Goutebroze, S. and Bublot, M. 2005. Efficacy of and HVT/VP2 vectored vaccine against vvIBD challenge after in ovo injection in presence of IBD maternal antibodies. In: Proceedings of the $14^{\text {th }}$ world veterinary poultry congress. pp. 279-287.

Müller, H., Islam, M. R. and Raue, R. 2003. Research on infectious bursal disease--the past, the present and the future. Vet. Microbiol., 97: 153-65.

Muller, H., Scholtissek, C. and Becht, H. 1979. The genome of infectious bursal disease virus consists of two segments of double-stranded RNA. J. Virol., 31: 584-589.

Perozo, F., Villegas, P., Fernandez, R., Cruz, J. and Pritchard, N. 2009. Efficacy of Single Dose Recombinant Herpesvirus of Turkey Infectious Bursal Disease Virus (IBDV) Vaccination Against a Variant IBDV Strain. Avian Dis., 53: 624-628.

Prandini, F., Bublot, M., Le Gros, F. X., Dancer, A., Pizzoni, L. and Lamichhane, C. 2008. Assessment of the immune response in two ELISA kits after in ovo or day-old vaccination with a vectored HVT + IBD vaccine (VAXXITEK ${ }^{\circledR}$ HVT). Zoo. Int., 9: 25-33.

Rautenschlein, S., Kraemer, C., Vanmarcke, J. and Montiel, E. 2005. Protective efficacy of intermediate and intermediate plus infectious bursal disease virus (IBDV) vaccines against very virulent IBDV in commercial broilers. Avian Dis., 49: 231-237.

Rosales, A. G., Villegas, P., Lukert, P. D., Fletcher, O. J., Mohamed, M. A. and Brown, J. 1989.Isolation, identification, and pathogenicity of two field strains of infectious bursal disease virus. Avian Dis., 33: 35-41.

Saif, Y. M. 1998. Infectious bursal disease and hemorrhagic enteritis. Poult. Sci., 77: 1186-1189.

Sharma, J. M., Kim, I. J., Rautenschlein, S. and Yeh, H. Y. 2000. Infectious bursal disease virus of chickens: pathogenesis and immunosuppression. Dev. Comp. Immunol., 24: 223-235.

Tsukamoto, K., Saito, S., Saeki, S., Tanimura, N., Isobe, T. and Mase, M. 2002.Complete, long-lasting protection against lethal infectious bursal disease virus challenge by a single vaccination with an avian herpesvirus vector expressing VP2 antigens. J. Virol., 76: 5637-5645.

Van den Berg, T. P., Morales, D., Enterradossi, N., Rivallan, G., Toquin, D., Raue, R., Zierenberg, K., Zhang, M. F., Zhu, Y. P., Wang, C. Q., Zheng, H. J., Wang, X., Chen, G. C., Lim, B. L. and Muller, H. 2004. Assessment of genetic, antigenic and pathotypic criteria for the characterization of IBDV strains. Avian Pathol., 33: 470-476.

Van den Berg, T. P., Gonze, M. and Meulemans, G. 1991. Acute infectious bursal disease in poultry: isolation and characterization of a highly virulent strain. Avian Pathol., 20: 133-143. 